\title{
Neutralizing Antibody Response and Associated Factors in Coronavirus-19 Disease (COVID-19) up to One Month: A Case-Series of 129 Hospitalized Patients
}

\author{
Aliye Bastug ( $\nabla$ dr.aliye@yahoo.com ) \\ Saglik Bilimleri Universitesi https://orcid.org/0000-0002-8831-4877 \\ Hurrem Bodur \\ Saglik Bilimleri Universitesi \\ Urartu Ozgur Safak \\ Bilkent University: Bilkent Universitesi
}

Nazlican Filazi

Ankara University Faculty of Veterinary Medicine: Ankara Universitesi Veteriner Fakultesi

Omer Aydos

Ankara City Hospital: Ankara Sehir Hastanesi

Ebru Sahin Kehribar

Bilkent University: Bilkent Universitesi

Alireza Hanifehnezhad

Ankara University: Ankara Universitesi

Sümeyye Kazancioglu

Ankara City Hospital: Ankara Sehir Hastanesi

\section{Recep Erdem Ahan}

Bilkent University: Bilkent Universitesi

\section{Volkan Aslan}

Bilkent University: Bilkent Universitesi

\section{Banu Cakir}

Hacettepe University: Hacettepe Universitesi

Ahmet Sertcelik

Hacettepe University: Hacettepe Universitesi

\section{Aykut Ozkul}

Ankara University Faculty of Veterinary Medicine: Ankara Universitesi Veteriner Fakultesi

\section{Research Article}

Keywords: Neutralizing antibodies, COVID-19, IgG, IgM, Antibody response, Humoral immunity 
Posted Date: March 12th, 2021

DOl: https://doi.org/10.21203/rs.3.rs-302704/v1

License: (c) (i) This work is licensed under a Creative Commons Attribution 4.0 International License. Read Full License 


\section{Abstract}

Purpose Little is known about the characteristics of neutralizing antibody(NAb) response in patients recovered COVID - 19. We aimed to elucidate the factors affecting presence and titers of in an early phase of infection up to 30 days.

Methods A total of 129 laboratory-confirmed COVID-19 patients in a tertiary-care hospital were enrolled. Clinical and laboratory data were obtained retrospectively. SARS-CoV-2 specific NAb, IgM, and IgG antibody responses were analyzed. NAb-positive and negative patients were compared, to examine potential associations between clinical, demographical, and laboratory characteristics and the presence/titers of NAb.

Results SARS-CoV-2 specific NAb, IgM and IgG were detected at the time of hospital discharge in $60.5 \%$, $30.2 \%$, and $51.9 \%$ of the patients, respectively. The presence of antibodies was $42.4 \%(\mathrm{NAb}), 20.3 \%(\operatorname{lgM})$ and $44.1 \%(\operatorname{IgG})$ among patients within 5-9 days since onset; increased to $79.5 \%(\mathrm{NAb}), 34.1 \%(\operatorname{IgM})$ and $47.7 \%(\mathrm{IgG})$ by $10-14$ days; and detected in $66.7 \%(\mathrm{NAb}), 50 \%(\mathrm{IgM}), 83.3 \%(\mathrm{lgG})$ at/after day- 15 , following symptom onset. The median titer of neutralizing antibody(SN 50) was significantly higher in severe patients( 25 versus $7.5, p=0.009)$. Of the 23 severe patients, $52.2 \%(n=12)$ had higher NAb titers (i.e., SN 50 $\geq 1: 25)$ when compared to that in non-severe patients $(p=0.021 ; O R=2.89 ; 95 \% \mathrm{Cl}=1.15-7.28)$, yet, potential effect of follow-up time on NAb status and titers could not be ruled out.

Conclusion Presence and higher titers of NAb were detected more in severe patients compared to their non-severe counterparts. Survival analysis suggested that this difference could at least be partially explained by the length of follow-up after symptoms' onset.

\section{Introduction}

COVID-19 pandemic threatens global public health besides its heavy economic and social impacts. The protective immune response elicited by primary infection is crucial to prevent re-infection. Limited information is available about the elicited protective immunity by SARS-CoV-2. In an animal study, acquired immunity due to primary infection with SARS-CoV-2 has been shown to protect against subsequent infections[1]. Although there are reports revealing humoral antibodies in recovered COVID-19 patients, the titers are very low in some patients[2,3]. Re-test positivity for SARS-CoV-2 PCR in recovered COVID-19 patients was also reported in the literature[4-6]. It is discussed that the degree of immunity may vary due to the characteristics of the patients[7,3]. It remains unclear, whether protective neutralizing antibodies(NAbs) triggered by the virus are present in all recovered COVID-19 patients, and (if so) how long NAbs last. In the absence of efficient evidence on the kinetics of humoral immune response, the risk of SARS-CoV-2 re-infection in humans cannot be validly assessed.

NAbs are crucial components of protective immunity that bind viral particles, thereby, prevent attachment and entry to the susceptible host cells. The S protein is the main determinant of SARS-CoV-2 infection, 
responsible for viral attachment, fusion, and entry into host cells[8]. Conventional virus-neutralizing assay(VNA) is the gold standard for determining NAbs[9].

The dynamics of NAb titers in COVID-19 and its association with clinical severity may have a significant impact on predictions about protective use of convalescent serum (passive immunization), implementation of plasma therapies, and effectiveness of vaccines. A case series of 129 laboratoryconfirmed COVID-19 patients, subsequently hospitalized in a tertiary care university hospital over for 45 days, were investigated retrospectively; indirect ELISA and VNA results at the time of hospital discharge were used in analyses.

\section{Materials And Methods}

\subsection{Ethical Statement:}

Serum samples for SARS-CoV-2 specific antibody screening were collected at the Infectious Disease Clinics, Ankara City Hospital, with the official permission from the Ministry of Health, and the approval of the study protocol from the Ethical Committee of Ankara City Hospital(E1-20-532).

\subsection{Study design and participants}

The study included data from 129 adult COVID-19 patients admitted to Ankara City Hospital, over a period of 45 days. All participants meet the diagnostic criteria for COVID-19 according to WHO interim guidance[10](Figure 1).

Demographical, clinical, laboratory tests, chest computer tomography (CT) findings, oro/nasopharyngeal swab sample RT-PCR results for SARS-CoV-2 were extracted from electronic medical records, and COVID19 case follow-up forms. Laboratory data collected at the time of admission were: complete blood count parameters (CBC), estimated glomerular filtration rate (eGFR), aspartate aminotransferase (AST), alanine aminotransferase (ALT), lactate dehydrogenase (LDH), creatine kinase (CK), prothrombin time (PT), activated partial thromboplastin time (aPTT), international normalized ratio (INR), fibrinogen, D-dimer, ferritin, C- reactive protein (CRP) and procalcitonin. CBC was analyzed using the ADVIA 2120 Hematology System (Siemens Healthcare Diagnostics, Erlangen, Germany). Biochemical analyses were performed using an Atellica Solution Immunoassay\&Clinical Chemistry Analyzer (Siemens Healthcare Diagnostics, Erlangen, Germany). eGFR values were measured using the CKD-EPI formula[11]. PT, aPTT, INR, fibrinogen, and D-dimer were performed using the Sysmex CS-5100 System (Siemens Healthcare Diagnostics, Erlangen, Germany).

Two patients were asymptomatic at admission, and these two were excluded in analyses based on the time from symptoms to testing. Patients were classified as severe and non-severe cases, in studying whether severity was associated with immunological response. Using the National Institutes of Health 
$(\mathrm{NIH})$ classification of COVID-19 patients, those with mild/moderate illness were categorized as nonsevere, while patients with severe/critical illness were grouped as severe patients[12].

Serum samples were obtained from patients on the day of hospital discharge to analyze antibody response. SARS-CoV-2 IgG were analyzed in sera samples using enzyme-linked immunosorbent assay (ELISA). The presence and titers of NAbs were analyzed with the virus neutralization assay (VNA). The time from symptoms onset to collection of serum samples was recorded for each patient for statistical analyses. Before performing the tests, the serum samples were heat inactivated at $56^{\circ} \mathrm{C}$ for 30 minutes and stored at $-20^{\circ} \mathrm{C}$ until their use.

\subsection{Production of in-house ELISA for Detection of SARS-CoV-2 IgG and IgM}

The receptor-binding domain(RBD) of SARS-CoV-2(MN908947) spike protein was expressed in the HEK293T cells (ATCC ${ }^{\circledR}$ CRL-3216), purified and used as the ELISA antigen. The details about the production method of recombinant RBD-Antigen for in-house ELISA tests were summarized in Supplemantary file 1. [13]. For negative controls in tests, serum samples from nine healthy volunteers were randomized into 3 groups, and pooled to obtain 3 different negative control(NC) samples. Each patient sample and the NC material was assayed in triplicate, and means of absorbance values were used for interpretation. The samples with mean optical densities(ODs) equal to or greater than 0.22 were evaluated positive, and equal to or less than 0.18 were negative. OD values between these values were deemed indeterminate.

\subsection{Virus Neutralization Assay (VNA)}

Virus neutralization assay was performed in microtiter plate as described by Hanifehnezhad et al[14]. Briefly, two-fold diluted serum samples, starting from 1:5 were mixed with an equal volume of $100 \mathrm{TCID}_{50}$ SARS-CoV-2 Ank1 isolate (1:10000) in quadruplicate, and incubated for $1 \mathrm{~h}$ at $37^{\circ} \mathrm{C}$ for neutralization. The serum-virus mixtures were subsequently inoculated onto 90\% confluent Vero E6 cells grown in 96-well plates. The VNA was evaluated via inverted microscope when $100 \%$ CPE was observed in virus control wells.

\subsection{Statistical analysis}

Statistical analyses were performed using Statistical Package for the Social Sciences (SPSS) version 21.0(Armonk, NY, USA). The Kolmogorov-Smirnov test was performed to check the normality of the variables. Descriptive analysis was presented using mean \pm SD for normally distributed variables and median (minimum-maximum value) for non-normally distributed variables. Demographic and laboratory data were compared with the Student's t-test for parametric and the Mann-Whitney U test for nonparametric variables. Comparisons for categorical variables were executed using the chi-square test or Fisher's exact test. Kruskal Wallis test was used for comparisons of more than two groups. Potential associations between disease severity and NAb status and titer were studied using Kaplan-Meier analysis, using time to event (presence of NAb or higher titer) as the time from initiation of symptoms through the date of hospital discharge (i.e., time of testing). Hazard ratios were obtained from Cox-regression models. 
Demographic and laboratory parameters were also compared to determine the factors that may have an impact on antibody response. Distributions of NAb titers among different patient sub-categories were analysed with Mann-Whitney U test, and plotted by GraphPad Prism version 9(GraphPad Software, SanDiego, California,USA). Statistical significance was defined as $p<0.05$ for all analyses.

\section{Results}

\subsection{Clinical and Radiological Characteristics of COVID-19 patients}

All 129 patients had chest CT findings and/or concordant symptoms for SARS- CoV-2 infection, in addition to laboratory confirmation with a positive PCR ( $n=97,75.2 \%)$ and/or antibody tests $(n=111,86 \%)$. The mean age of the patients was $46.4 \pm 15.8$ years, and $54.3 \%$ of them were male. The median length of hospital stay was 7 days (min-max; 1 - 24days). Dry cough, fever and dyspnea were the most relevant symptoms of remained patients, with the frequency of $64.8 \%, 45.7 \%$ and $27.1 \%$, respectively. Of these, fever and dyspnea were statistically more frequent in patients producing Nabs ( $52.6 \%$ vs $35.3 \%, p=0.05$ and $33.3 \%$ vs $17.6 \%, p=0.05$, respectively).

Serum samples were obtained from all for antibodies against SARS-CoV-2. Given that the period of hospitalization varied based on the clinical status and treatment modalities used for each patient, hospitalization periods were grouped for analyses into three, as 5-9, 10-14 and 15-28 days. The median time from onset of symptoms to antibody test was 11 days (ranging from 5 to 28 days). The incident rate of developing NAbs were found to be 5.6 per 100 person-days among patients tested for NAbs between 5 to 9 days of the initiation of symptoms; 6.5 per 100 person-days among patients tested for NAbs between 10 to 14 days; and, 3.7 per 100 person-days among patients tested for NAbs between 15 to 28 days. Abnormalities on chest CT were significantly higher in patients who elicited NAbs ( $94.9 \%$ vs $72.5 \%$, $p<0.001$ ). Bilateral multi-lobar ground glass opacities and consolidation, i.e., advanced stage CT findings, were significantly more frequent in those eliciting NAbs at hospital discharge $(p=0.012)($ Table 1$)$.

The distribution of NAb titers which analysed in discharge serum of the patients were plotted based on age, gender, disease severity and chest CT findings at the time of admission (Figure 2). NAb titers were not significantly different according to age or gender (Figure 2A, 2B). The median NAb titer was significantly higher $(p=0.008)$ in severe patients $\left(\mathrm{SN}_{50} ; 1: 25\right.$, IQR 1:42.5) when compared non-severe counterparts ( $\mathrm{SN}_{50} ; 1: 7.5$, IQR 1:25) (Figure $2 \mathrm{C}$ ). The median NAb titers were 1:17.5(Interquartile range (IQR); 1:20) and 1:7.5(IQR; 1:17.5) in the patients with advanced and early stage findings on thorax CT, respectively. There was a statistically significant different between these groups $(p=0.006)$ (Figure 2D

Severe patients consisted of $17.8 \%(n=23)$, of which nine (39.1\%) required ICU support on the follow up. They were older than their counterparts in the non-severe group (mean ages were $60.9 \pm 13.5$ vs $43.4 \pm$ 14.7 years, respectively, $p<0.001$ counterparts). Hypertension was determined significantly common in severe group $(p=0.007)$ and those who developed dyspnea and needed oxygen support with nasal cannula more frequently $(p<0.001$ ) (Supplemantary Table 1 ). Significantly higher AST, LDH, CK, PT, INR, D- 
dimer, CRP, ferritin, neutrophil lymphocyte ratio (NLR), lower lymphocyte levels, and eGFR were more prevalent on admission in the severe group compared to their counterparts in the non-severe group (all $p<0.05$, Supplemantary Table 2).

\section{2 Seroconversion Characteristics of NAbs, IgM, and IgG against SARS-CoV-2}

The seroconversion rate at the time of hospital discharge were $60.5 \%, 30.2 \%$, and $51.9 \%$ for $\mathrm{NAb}$, $\operatorname{lgM}$, and IgG, respectively. Using VNA as the reference test, the sensitivity of the $\lg G$ was $85.9 \%$ and the specificity was $72.5 \%$. The median time to testing(discharge) were longer (12 versus 8 days, $p<0.001$ ) in the group with NAb positivity at discharge. NAb positivity was significantly higher ( $75 \%$ vs $42.4 \%, p<0.001)$ after 10 days from symptoms onset; NAb positivity was the highest (79.5\%) among those who were tested 10-14 days after their symptoms' onset $(p<0.001)$ (Figure 3$)$. It is remarkable that, 34 patients $(26.4 \%$ of total patients) who remained seronegative for NAbs, were discharged in less than 10 days.

IgM and IgG antibody response were $20.3 \%$ and $44.1 \%$ among patients within $5-9$ days since onset, and increased to $34.1 \%$ and $47.7 \%$ within $10-14$ days; the highest levels $50 \%$ and $83.3 \%$ were detected respectively, among patients tested 15 days (max follow-up was 28 days) after the onset of symptoms (Figure 3).

Seroconversion rates of IgG response was statistically significantly ( $82.6 \%$ vs $45.3 \%, p=0.006)$ and frequency of NAb positivity was slightly higher in the severe group ( $78.3 \%$ vs $56.6 \% p=0.05)$. Eight of the nine patients (88.9\%) who needed ICU support over hospitalization elicited NAbs. Additionally, median $\mathrm{NAb}$ titers $\left(\mathrm{SN}_{50}\right.$ level) were significantly higher in patients with severe infection (median 25 vs 7.5, $p=0.009)$. Out of 23 severe patients, $52.2 \%(n=12)$ had higher NAb titers $\left(\mathrm{SN}_{50} \geq 1: 25\right)$; the odds of high NAb were 2.89 times among severe patients compared to non-severe patients $(95 \% \mathrm{Cl}=1.15-7.28, \mathrm{p}=$ 0.021) (Supplemantary Table 1).

\subsection{Comparison of the VNA and ELISA}

A total of 129 discharged serum samples of the patients were analyzed with both a in-house ELISA kit, and VNA assay. We found that, 67 (51.9\%) samples were positive in IgG ELISA and 78(60.5\%) samples were positive in VNA. In addition, $53(41.1 \%)$ samples were positive and $37(28.7 \%)$ were negative in both assays. Fourteen samples were found to be VNA negative but ELISA positive, whilst 22 samples were VNA positive but ELISA negative. Three samples were indeterminate in ELISA while positive with VNA (Table 1). Accordingly, sensitivity and specificity values of ELISA were $67.9 \%$ and $72.5 \%$, respectively, in determining immunity in patients recovered from COVID-19.

\subsection{The relation of NAbs with laboratory parameters in COVID-19 patients}

The distribution of laboratory parameters of the patients by NAbs positivity revealed that CRP, AST, LDH, CK were all significantly higher in patients with NAbs positivity (Table 2). The correlation analyses were performed to determine the predictors of higher NAb titers ( $\mathrm{SN}_{50}$ levels). There was a weak, positive 
correlation between $\mathrm{SN}_{50}$ levels and antibody testing time (i.e., the length of days after symptoms' onset), NLR, AST, LDH, CK, ferritin, PT and INR; whilst lymphocyte level had a weak, negative correlation (Supplemantary Table 3).

\subsection{Association between disease severity and presence and higher titers of NAb}

The rate ratios for the presence of NAbs at hospital discharge were 1.16 and 0.66 , comparing patients with discharge at days 10-14 and 15-28, respectively, with patients discharged before 10 days after symptoms onset. Kaplan-Meier analyses revealed that both NAb production started earlier and was more prominent among non-severe cases than severe cases, if followed over time. A similar course was observed for higher NAb titers, comparing severe and non-severe cases. The significant difference obtained for higher NAb titers favoring severe cases $(p=0.02)$ in binary analyses disappeared when timeto-event was controlled for. Survival analysis revealed a negative association between severity and presence of NAb at hospital discharge (Figure 4).

\section{Discussion}

Host immune response is the key component to prevent re-infection from the same pathogen. The characteristics and dynamics of NAb response to SARS-CoV-2 infection remain poorly understood. The reinfection risk for recovered patients is still a global concern[4]. There are many questions to be explained, including the percentage of patients eliciting NAb after primary infection in protective titer, and whether there is a correlation between the clinical course of COVID-19 and the NAb response.

In this study, we investigated IgM, IgG and NAb response in sera of confirmed COVID-19 patients at the time of hospital discharge. Additionally, the association between severity of illness, laboratory parameters on admission and antibody response presence and high titers) were evaluated.

Proportional prevalence of IgM was reported lower than IgG prevalence in a study aiming to investigate acute antibody responses in a cohort having various clinical aspects of COVID-19[15]. In addition, initial occurrence of IgM and IgG antibodies was found different in various patients. Wang et al. also reported two patients with confirmed COVID-19 pneumonia failed to produce either $\operatorname{lgM}$ or $\lg$ even 40 to 50 days after their symptom's onset[16]. Similarly, IgM was found under the detection limit in $69.8 \%$ of the patients for 29 days in our investigation. It was expected more patients with higher IgM response during this time. In addition, having neutralizing antibody prevalence more than $60 \%$ may indicate that ELISA protocol generated has limited performance in detection of RBD specific antibodies. This limitation needs to be confirmed by re-testing samples using ELISA protocols targeting $\mathrm{N}$ protein specific antibody responses.

It is known that antibody response is expected around 7-10 days after the onset of viral infection[7]. In the present study, antibody testing was conducted at the time of hospital discharge, to maximize the time interval between the time of testing and the onset of symptoms. Given that patients varied in clinical severity at admission, period of hospitalization varied, as well. The median time to antibody test were 11 days (ranged 5-28 days) after the onset of symptoms. This limitation in the study lead to varying 
durations between onset of symptoms and time for testing, which might have hindered our ability to detect NAb presence among those discharged from hospital early.

Yuchun et al. reported that $85.9 \%$ of the patients with SARS-CoV infection had positive NAb responses which was first detectable from day 5 after the onset of symptoms and reached a peak level between days 20-30[17]. In our study population, NAb was detected in $42.4 \%$ of the patients, positivity reached a peak among those tested at days 10-14 days after symptoms' onset, but decreased to lower levels among those hospitalized longer than 15 days. Inability to present a dose-response effect (if any) could be linked to a detection bias in the study given that these tests were not longitudinal measurements in the same cohort, but could have been different due to variations in patient profile which could be a direct predictor of hospital stay. Future cohorts of adequate size are clearly warranted to reveal the exact pattern(s) of antibody levels over time, extending to months and even years, following COVID-19 infection.

Previous study showed that some of COVID-19 patients had very low NAb titers against SARS-CoV2[3]. In our study, more than two thirds of the patients had negative $(39.5 \%)$ or low titers $\left(\mathrm{SN}_{50}<1: 25\right)$ of NAbs, although all (except one) were recovered successfully. Of all patients, about one-tenth had no detectable NAb, despite presence of IgGs. These results suggesting that cellular immunity (T Cells; Th1 responses and cytotoxic CD8 cells) may have an impact on recovery of the patients, in the absence of detectable humoral immune response. The important role of $\mathrm{T}$ cell-mediated immunity to control infection was reported previously[18].

At the other end, two male patients had remarkably high $\mathrm{SN}_{50}$ levels (>1:1250). One of them was 36 years old with nonsevere SARS-CoV-2 infection; tested on day-12; the other was 50 years old, with severe COVID-19 and was tested on day-28. Both were discharged healthy.

Zhao et al. found quantitative antibody titers as independent factors predicting clinical severity[19], but this was not confirmed by Yuchun et al.,leading to the assumption that lung damage and worsening in clinical course by the second week of infection may be due to the exaggerated immune response rather than uncontrolled viral replication[17,20], as raised by Peiris et al, earlier. Moderbacher et al. was also reported that no significant associations was found between SARS-CoV-2 antibodies and disease severity instead associations were found between strong specific T cell responses and low COVID-19 disease severity[18]. In our study, NAb presence was negatively associated with disease severity when time-toevent was controlled for $(p=0.02)$. Variations in definition of severity (with or without control for potential confounders, including patient characteristics and laboratory findings) may lead to inconsistent findings in different studies. Future studies are clearly warranted to elucidate the mechanisms underlying NAb response in COVID-19 patients.

Wu et al, reported that the NAb titers positively correlated with age and CRP levels and negatively correlated with lymphocyte counts on admission[3]. Additionally, Chen et al. reported that the patients with older age, higher CRP and LDH levels and with more profound lung involvement had higher titers of NAbs[21]. In line with this report, our patients with advance stage CT findings had significantly higher NAb 
titers, and NAb titers positively correlated with NLR, AST, LDH, CK, ferritin, CRP, and INR, and significantly yet negatively associated with lymphocyte levels.

There is a great need for effective treatment strategies to combat this pandemic. Although there are many challenges, convalescent plasma or sera therapies consisting of NAbs may have a potential efficacy to clear the virus, if it is provided in the early stage of infection. In light of the information obtained from the present study, we suggested that convalescent plasma donors should be selected carefully between the recovered patients. The titration of NAb should be performed before using convalescent sera or plasma for therapy. On the other hand, this is also important since antibodies other than NAbs targeting receptor-binding domains of $S$ protein may exaggregate immune response and may cause antibody-dependent enhancement(ADE) as it was reported in SARS[22].

There were some limitations in our study. Our sample size was limited, with only two asymptomatic patients, both developed NAbs; thus, further analyses were restricted to symptomatic patients, only. In studying the potential association between time of testing and onset of symptoms, variations of hospitalization periods (5-28 days after symptom onset) might have obscured a doseresponse effect (if any), given that convalensent sera were obtained only once. Patient profile and clinical condition could have directly affected the hospitalization period, thus, comparison of NAb titers across the 3 groups (based on hospitalization periods) might be confounded by some uncontrolled factors. The "high NAb titer" was determined in the study based on the median $\mathrm{SN}_{50}$ level (1:25) in study population. Further studies are needed to assess the accuracy of predictors of higher titers of NAbs, for $\mathrm{SN}_{50}$ levels $\geq 1: 250$ or so. Lastly, cellular immune response in recovered patients was beyond the scope of our study.

Despite its limitations, to our knowledge, this is the first NAb study in our population; and, revealed significant associations between clinical findings on admission and higher NAb titers, suggesting that such factors should be considered in future studies on immune response to COVID-19. Finding of a negative association between disease severity and NAb presence/titers deserves special attention in developing alternative pathophysiological explanations, if confirmed in other studies. Periodical testing of NAbs among COVID-19 patients is warranted for valid investigation of the nature of immunological response, and its implications on various therapeutic interventions and herd immunity.

Large, heterogeneous cohorts of COVID-19 patients are clearly warranted to investigate (both humoral and cellular) immune response after recovery and how it is linked with future health problems, including re-infection with SARS-CoV-2. It is noteworthy that periodical measurements at pre-defined, fixed time knots are crucial for comparability between sub-populations and across studies.

\section{Declarations}

\section{Funding}


This research did not receive any specific grant from funding agencies in the public, commercial, or notfor-profit sectors.

\section{Declaration of Competing Interest}

The authors declare that they have no known competing interests.

\section{Availability of data and material: Available if request}

\section{Code availability}

Not applicable

\section{Author's contributions}

$\mathrm{AB}, \mathrm{HB}, \mathrm{SK}, \mathrm{OA}$ are clinicians and provided clinical details. $\mathrm{BC}$ and $\mathrm{AS}$ conducted statistical analysis and composed the figure. $A B, A O$, OSUS and $\mathrm{HB}$ wrote and edited the manuscript. All authors were involved in the gathering of the manuscript and approved the final version.

\section{Credit authorship contribution statement}

Conception and study design: Bastug Aliye, Bodur Hurrem, Ozkul Aykut

Writing - original draft: Bastug Aliye

Writing_ review \& editing: Bastug Aliye, Bodur Hurrem, Ozkul Aykut, Seker Ozgur Safak Urartu, Methodology: Ozkul Aykut, Seker Ozgur Safak Urartu, Bastug Aliye

Statistical analysis: Cakir Banu, Sertcelik Ahmet

Data collection: Bastug Aliye, Aydos Omer, Kazancioglu Sumeyye

Laboratory Investigation: Ozkul Aykut, Filazi Nazlican, Hanifehnezhad Alireza, Seker Ozgur Safak Urartu, Kehribar Ebru Sahin, Ahan Recep Erdem, Aslan Volkan

Final approval of the manuscript: All authors

Ethics approval: Official permission was obtained from the Ministry of Health, and the approval of the study protocol from the Ethical Committee of Ankara City Hospital (E1-20-532).

Consent to participate and publication: Informed consent to participation and publication were obtained from the patients

Acknowledgments: Not applicable

\section{References}


1. Ota M (2020) Will we see protection or reinfection in COVID-19? Nat Rev Immunol 20 (6):351. doi:https://doi.org/10.1038/s41577-020-0316-3

2. To KK-W, Tsang OT-Y, Leung W-S, Tam AR, Wu T-C, Lung DC, Yip CC-Y, Cai J-P, Chan JM-C, Chik TS-H (2020) Temporal profiles of viral load in posterior oropharyngeal saliva samples and serum antibody responses during infection by SARS-CoV-2: an observational cohort study. The Lancet Infectious Diseases. doi:https://doi.org/10.1016/S1473-3099(20)30196-1

3. Wu F, Wang A, Liu M, Wang Q, Chen J, Xia S, Ling Y, Zhang Y, Xun J, Lu L (2020) Neutralizing antibody responses to SARS-CoV-2 in a COVID-19 recovered patient cohort and their implications. doi:https://doi.org/10.1101/2020.03.30.20047365

4. Kang H, Wang Y, Tong Z, Liu X (2020) Retest positive for SARS-CoV-2 RNA of "recovered" patients with COVID-19: Persistence, sampling issues, or re-infection? J Med Virol. doi:https://doi.org/10.1002/jmv.26114

5. Lan L, Xu D, Ye G, Xia C, Wang S, Li Y, Xu H (2020) Positive RT-PCR test results in patients recovered from COVID-19. Jama 323 (15):1502-1503. doi:https://doi.org/10.1001/jama.2020.2783

6. Fu W, Chen Q, Wang T (2020) Letter to the Editor: Three cases of re-detectable positive SARS-CoV-2 RNA in recovered COVID-19 patients with antibodies. Journal of Medical Virology. doi:https://doi.org/10.1002/jmv.25968

7. Leung H (2020) Can You Be Re-Infected After Recovering From Coronavirus? Here's What We Know About COVID-19 Immunity. Retrieved 4 (30):2020

8. Pillay TS (2020) Gene of the month: the 2019-nCoV/SARS-CoV-2 novel coronavirus spike protein. Journal of Clinical Pathology. doi:https://doi.org/10.1136/jclinpath-2020-206658

9. Okba NM, Muller MA, Li W, Wang C, GeurtsvanKessel CH, Corman VM, Lamers MM, Sikkema RS, de Bruin E, Chandler FD (2020) SARS-CoV-2 specific antibody responses in COVID-19 patients. medRxiv. doi:https://doi.org/10.1101/2020.03.18.20038059

10. Organization WH (2020) Clinical management of severe acute respiratory infection (SARI) when COVID-19 disease is suspected: interim guidance, 13 March 2020. World Health Organization,

11. Levey AS, Stevens LA, Schmid CH, Zhang YL, Castro AF, Feldman HI, Kusek JW, Eggers P, Van Lente F, Greene T (2009) A new equation to estimate glomerular filtration rate. Annals of internal medicine 150 (9):604-612. doi:https://doi.org/10.7326/0003-4819-150-9-200905050-00006

12. Health NIo COVID-19 Treatment Guidelines Panel. Coronavirus Disease 2019 (COVID-19) Treatment Guidelines. 2020 [cited 2020 29.05].

13. Taylor MJ, Perrais D, Merrifield CJ (2011) A high precision survey of the molecular dynamics of mammalian clathrin-mediated endocytosis. PLoS biol 9 (3):e1000604. doi:https://doi.org/10.1371/journal.pbio.1000604

14. Hanifehnezhad A, Kehribar EŞ, Öztop S, Sheraz A, Kasırga S, Ergünay K, Önder S, Yılmaz E, Engin D, Oğuzoğlu TÇ (2020) Characterization of local SARS-CoV-2 isolatesand pathogenicity in IFNAR-/mice. Heliyon 6 (9):e05116. doi:https://doi.org/10.1016/j.heliyon.2020.e05116 
15. Long Q-X, Liu B-Z, Deng H-J, Wu G-C, Deng K, Chen Y-K, Liao P, Qiu J-F, Lin Y, Cai X-F (2020) Antibody responses to SARS-CoV-2 in patients with COVID-19. Nature medicine:1-4.

doi:https://doi.org/10.1038/s41591-020-0897-1

16. Wang J, Chen C, Li Q, Cai P, Wang Z, Wang L (2020) COVID-19 confirmed patients with negative antibodies results. BMC infectious diseases 20 (1):1-4. doi:https://doi.org/10.1186/s12879-02005419-3

17. Yuchun N, Guangwen W, Xuanling S, Hong Z, Yan Q, Zhongping H, Wei W, Gewei L, Xiaolei Y, Liying D (2004) Neutralizing antibodies in patients with severe acute respiratory syndrome-associated coronavirus infection. The Journal of infectious diseases 190 (6):1119.

doi:https://doi.org/10.1086/423286

18. Moderbacher CR, Ramirez SI, Dan JM, Grifoni A, Hastie KM, Weiskopf D, Belanger S, Abbott RK, Kim C, Choi J (2020) Antigen-specific adaptive immunity to SARS-CoV-2 in acute COVID-19 and associations with age and disease severity. Cell. doi:https://doi.org/10.1016/j.cell.2020.09.038

19. Zhao J, Yuan Q, Wang H, Liu W, Liao X, Su Y, Wang X, Yuan J, Li T, Li J (2020) Antibody responses to SARS-CoV-2 in patients of novel coronavirus disease 2019. Clinical Infectious Diseases. doi:https://doi.org/10.1093/cid/ciaa344

20. Peiris JSM, Chu C-M, Cheng VC-C, Chan K, Hung I, Poon LL, Law K-I, Tang B, Hon T, Chan C (2003) Clinical progression and viral load in a community outbreak of coronavirus-associated SARS pneumonia: a prospective study. The Lancet 361 (9371):1767-1772.

doi:https://doi.org/10.1016/s0140-6736(03)13412-5

21. Chen W, Zhang J, Qin X, Wang W, Xu M, Wang L-F, Xu C, Tang S, Liu P, Zhang L (2020) SARS-CoV-2 neutralizing antibody levels are correlated with severity of COVID-19 pneumonia. Biomedicine \& Pharmacotherapy 130:110629. doi:https://doi.org/10.1016/j.biopha.2020.110629

22. Du L, He Y, Zhou Y, Liu S, Zheng B-J, Jiang S (2009) The spike protein of SARS-CoV-a target for vaccine and therapeutic development. Nature Reviews Microbiology 7 (3):226-236. doi:https://doi.org/10.1038/nrmicro2090

\section{Tables}

Table 1. Demographic, clinical and radiologic characteristics of the patients with COVID-19 


\begin{tabular}{|c|c|c|c|c|c|c|c|}
\hline & $\begin{array}{l}\text { Total } \\
\mathrm{N}=129 \\
(\%)\end{array}$ & $\begin{array}{l}\text { NAbs } \\
\text { positive } \\
\text { patients } \\
\mathrm{N}=78(\%)\end{array}$ & $\begin{array}{l}\text { NAbs } \\
\text { negative } \\
\text { patients } \\
\mathrm{N}=51(\%)\end{array}$ & $\begin{array}{l}P \\
\text { value }^{\&}\end{array}$ & $\begin{array}{l}\mathrm{SN}_{50} \\
\geq 1: 25 \\
\mathrm{~N}=41 \\
(\%)\end{array}$ & $\begin{array}{l}\mathrm{SN}_{50} \\
<1: 25 \\
\mathrm{~N}=88(\%)\end{array}$ & $\begin{array}{l}\text { P } \\
\text { Value }\end{array}$ \\
\hline $\begin{array}{l}\text { Age, mean } \pm S D \text {, } \\
\text { years }\end{array}$ & $\begin{array}{l}46.4 \pm \\
15.8\end{array}$ & $\begin{array}{l}48.1 \pm \\
14.7\end{array}$ & $44 \pm 17.5$ & $>0.05$ & $\begin{array}{l}49.7 \pm \\
16.4\end{array}$ & $\begin{array}{l}44.9 \pm \\
16.4\end{array}$ & 0.076 \\
\hline Male gender & $\begin{array}{l}70 \\
(54.3)\end{array}$ & $45(57.7)$ & $25(49)$ & $>0.05$ & $\begin{array}{l}27 \\
(65.9)\end{array}$ & $43(48.9)$ & 0.07 \\
\hline $\begin{array}{l}\text { Healthcare } \\
\text { professional }\end{array}$ & $\begin{array}{l}10 \\
(7.8)\end{array}$ & $5(6.4)$ & $5(9.8)$ & $>0.05$ & $2(4.9)$ & $8(9.1)$ & $>0.05$ \\
\hline $\begin{array}{l}\text { Contact with a } \\
\text { Positive Case }\end{array}$ & $\begin{array}{l}60 \\
(46.5)\end{array}$ & $40(51.3)$ & $20(39.2)$ & $>0.05$ & $\begin{array}{l}17 \\
(41.5)\end{array}$ & $43(48.9)$ & $>0.05$ \\
\hline PCR Confirmation & $\begin{array}{l}97 \\
(75.2)\end{array}$ & $55(70.5)$ & $42(82.4)$ & $>0.05$ & $\begin{array}{l}25 \\
(61)\end{array}$ & $72(81.8)$ & 0.011 \\
\hline NAbs positivity & $\begin{array}{l}78 \\
(60.5)\end{array}$ & $78(100)$ & & & $\begin{array}{l}41 \\
(100)\end{array}$ & $37(34.1)$ & $<0.001$ \\
\hline $\begin{array}{l}\text { NAbs titer (SN50), } \\
\text { median (min-max) }\end{array}$ & $\begin{array}{l}7.5(0 \\
- \\
1250)\end{array}$ & $\begin{array}{l}25(5- \\
1250)\end{array}$ & & & $\begin{array}{l}25(25 \\
-1250)\end{array}$ & $0(0-10)$ & $<0.001$ \\
\hline \multicolumn{8}{|l|}{ IgG antibody } \\
\hline Positive & $\begin{array}{l}67 \\
(51.9)\end{array}$ & $53(67.9)$ & $14(27.5)$ & \multirow{3}{*}{$\dot{0} 001$} & $\begin{array}{l}37 \\
(90.2)\end{array}$ & $30(34.1)$ & \multirow{3}{*}{$<0.001$} \\
\hline Negative & $\begin{array}{l}59 \\
(45.7)\end{array}$ & $22(28.2)$ & $37(72.5)$ & & $\begin{array}{l}2 \\
(48.8)\end{array}$ & $57(64.8)$ & \\
\hline Indetermine & $3(2.3)$ & $3(3.8)$ & - & & $2(4.9)$ & $1(1.1)$ & \\
\hline \multicolumn{8}{|l|}{ IgM antibody } \\
\hline Positive & $\begin{array}{l}39 \\
(30.2)\end{array}$ & $37(47.7)$ & $2(3.9)$ & \multirow[t]{3}{*}{$<0.001$} & $\begin{array}{l}28 \\
(68.3)\end{array}$ & 11 (12.5) & \multirow[t]{3}{*}{$<0.001$} \\
\hline Negative & $\begin{array}{l}88 \\
(68.2)\end{array}$ & $39(50.0)$ & $49(96.1)$ & & $\begin{array}{l}13 \\
(31.7)\end{array}$ & $75(85.2)$ & \\
\hline Indetermine & $2(1.6)$ & $2(2.6)$ & - & & - & $2(2.3)$ & \\
\hline Severe patients & $\begin{array}{l}23 \\
(17.8)\end{array}$ & $18(23.1)$ & $5(9.8)$ & 0.05 & $\begin{array}{l}12 \\
(29.3)\end{array}$ & $11(12.5)$ & 0.021 \\
\hline $\begin{array}{l}\text { Onset of symptoms } \\
\text { to antibody test*, } \\
\text { median day (min- } \\
\text { max) }\end{array}$ & $\begin{array}{l}11(5- \\
28)\end{array}$ & $12(5-28)$ & $8(5-22)$ & $\dot{0} 001$ & $\begin{array}{l}12(7- \\
28)\end{array}$ & $9(5-23)$ & $<0.001$ \\
\hline
\end{tabular}




\begin{tabular}{|c|c|c|c|c|c|c|c|}
\hline & $\begin{array}{l}\text { Total } \\
\mathrm{N}=129 \\
(\%)\end{array}$ & $\begin{array}{l}\text { Neutralizing } \\
\text { antibody } \\
\text { positive } \\
\text { patients } \\
\mathrm{N}=78(\%)\end{array}$ & $\begin{array}{l}\text { Neutralizing } \\
\text { antibody } \\
\text { negative } \\
\text { patients } \\
\mathrm{N}=51(\%)\end{array}$ & $\begin{array}{l}\text { P } \\
\text { value }^{\&}\end{array}$ & $\begin{array}{l}\mathrm{SN}_{50} \\
\geq 1: 25 \\
\mathrm{~N}=41 \\
(\%)\end{array}$ & $\begin{array}{l}\mathrm{SN}_{50} \\
<1: 25 \\
\mathrm{~N}=88(\%)\end{array}$ & $\begin{array}{l}\text { P } \\
\text { Value } 8 \&\end{array}$ \\
\hline $\begin{array}{l}\text { Abnormalities } \\
\text { on chest CT }\end{array}$ & $111(86)$ & $74(94.9)$ & $37(72.5)$ & $\hat{0.001}$ & $\begin{array}{l}41 \\
(100)\end{array}$ & $\begin{array}{l}70 \\
(79.5)\end{array}$ & $<0.001$ \\
\hline $\begin{array}{c}\text { Early } \\
\text { stage }\end{array}$ & $\begin{array}{l}75 \\
(58.1)\end{array}$ & $46(59)$ & $29(57)$ & \multirow{2}{*}{0.012} & $\begin{array}{l}23 \\
(56.1)\end{array}$ & $\begin{array}{l}52 \\
(59.1)\end{array}$ & \multirow[t]{2}{*}{0.012} \\
\hline $\begin{array}{l}\text { Advanced } \\
\text { stage } \mathrm{e}^{\star \star \star}\end{array}$ & $\begin{array}{l}36 \\
(35.2)\end{array}$ & $28(35.9)$ & $8(15.7)$ & & $\begin{array}{l}18 \\
(43.9)\end{array}$ & $\begin{array}{l}18 \\
(20.5)\end{array}$ & \\
\hline $\begin{array}{l}\text { Onset of } \\
\text { Symptom to } \\
\text { Hospital } \\
\text { admission*, } \\
\text { median day } \\
\text { (min-max) }\end{array}$ & $5(0-15)$ & $5(1-15)$ & $4(0-14)$ & 0.05 & $\begin{array}{l}6(1 \\
-15)\end{array}$ & $\begin{array}{l}5(0- \\
15)\end{array}$ & $>0.05$ \\
\hline $\begin{array}{l}\text { Length of } \\
\text { Hospital Stay, } \\
\text { median day } \\
\text { (min-max) }\end{array}$ & $7(1-24)$ & $8(3-24)$ & $7(1-15)$ & 0.012 & $\begin{array}{l}8(3- \\
24)\end{array}$ & $7(1-16)$ & 0.046 \\
\hline $\begin{array}{l}\text { ICU requirement } \\
(n=9)\end{array}$ & $9(7)$ & $8(10.3)$ & $1(2)$ & 0.087 & $\begin{array}{l}5 \\
(12.2)\end{array}$ & $4(4.5)$ & $>0.05$ \\
\hline $\begin{array}{l}\text { APACHE II } \\
\text { score, median } \\
\text { (min-max) }\end{array}$ & $6(3-40)$ & $8(3-40)$ & 3 & $>0.05$ & $\begin{array}{l}10(3- \\
11)\end{array}$ & $\begin{array}{l}4.5(3- \\
40)\end{array}$ & $>0.05$ \\
\hline Comorbidity & $\begin{array}{l}40 \\
(31.0)\end{array}$ & $24(30.8)$ & $16(31.4)$ & $>0.05$ & $\begin{array}{l}12 \\
(29.3)\end{array}$ & $\begin{array}{l}28 \\
(31.8)\end{array}$ & $>0.05$ \\
\hline Diabetes & $11(8.5)$ & $8(10.3)$ & $3(5.9)$ & $>0.05$ & $\begin{array}{l}4 \\
(9.8)\end{array}$ & $7(8)$ & $>0.05$ \\
\hline Hypertension & $\begin{array}{l}26 \\
(20.2)\end{array}$ & $16(20.5)$ & $10(19.6)$ & $>0.05$ & $9(22)$ & $\begin{array}{l}16 \\
(18.2)\end{array}$ & $>0.05$ \\
\hline COPD & $10(7.8)$ & $5(6.4)$ & $5(9.8)$ & $>0.05$ & $\begin{array}{l}2 \\
(4.9)\end{array}$ & $8(9.1)$ & $>0.05$ \\
\hline $\begin{array}{l}\text { Cardiovascular } \\
\text { disease }\end{array}$ & $7(5.4)$ & $4(5.1)$ & $3(5.9)$ & $>0.05$ & $\begin{array}{l}2 \\
(4.9)\end{array}$ & $5(5.7)$ & $>0.05$ \\
\hline $\begin{array}{l}\text { Respiratory rate } \\
\text { (/min), median } \\
\text { (min-max) }\end{array}$ & $\begin{array}{l}22(16- \\
36)\end{array}$ & $22(16-28)$ & $22(16-36)$ & $>0.05$ & $\begin{array}{l}22 \\
(18- \\
36)\end{array}$ & $\begin{array}{l}22(16- \\
28)\end{array}$ & $<0.001$ \\
\hline
\end{tabular}




\begin{tabular}{|clllllll|} 
Asymptomatic & $2(1.6)$ & $2(2.6)$ & - & NA & $\begin{array}{l}1 \\
(2.4)\end{array}$ & $1(1.1)$ & NA \\
\hline Fever & 59 & $41(52.6)$ & $18(35.3)$ & 0.05 & $\begin{array}{l}20 \\
(48.8)\end{array}$ & $\begin{array}{l}39 \\
(44.3)\end{array}$ & $>0.05$ \\
& $(45.7)$ & & & & & \\
Dry Cough & $83(64.8)$ & $49(63.6)$ & $34(66.7)$ & $>0.05$ & $\begin{array}{l}26 \\
(63.4)\end{array}$ & $\begin{array}{l}57 \\
(64.8)\end{array}$ & $>0.05$ \\
& & & & & & \\
Dyspnea & 35 & $26(33.3)$ & $9(17.6)$ & 0.05 & 18 & 17 & 0.003 \\
& $(27.1)$ & & & & $(43.9)$ & $(19.3)$ & \\
\hline Diarrhea & $7(5.4)$ & $5(6.4)$ & $2(3.9)$ & $>0.05$ & 1 & $6(6.8)$ & $>0.05$ \\
\hline
\end{tabular}




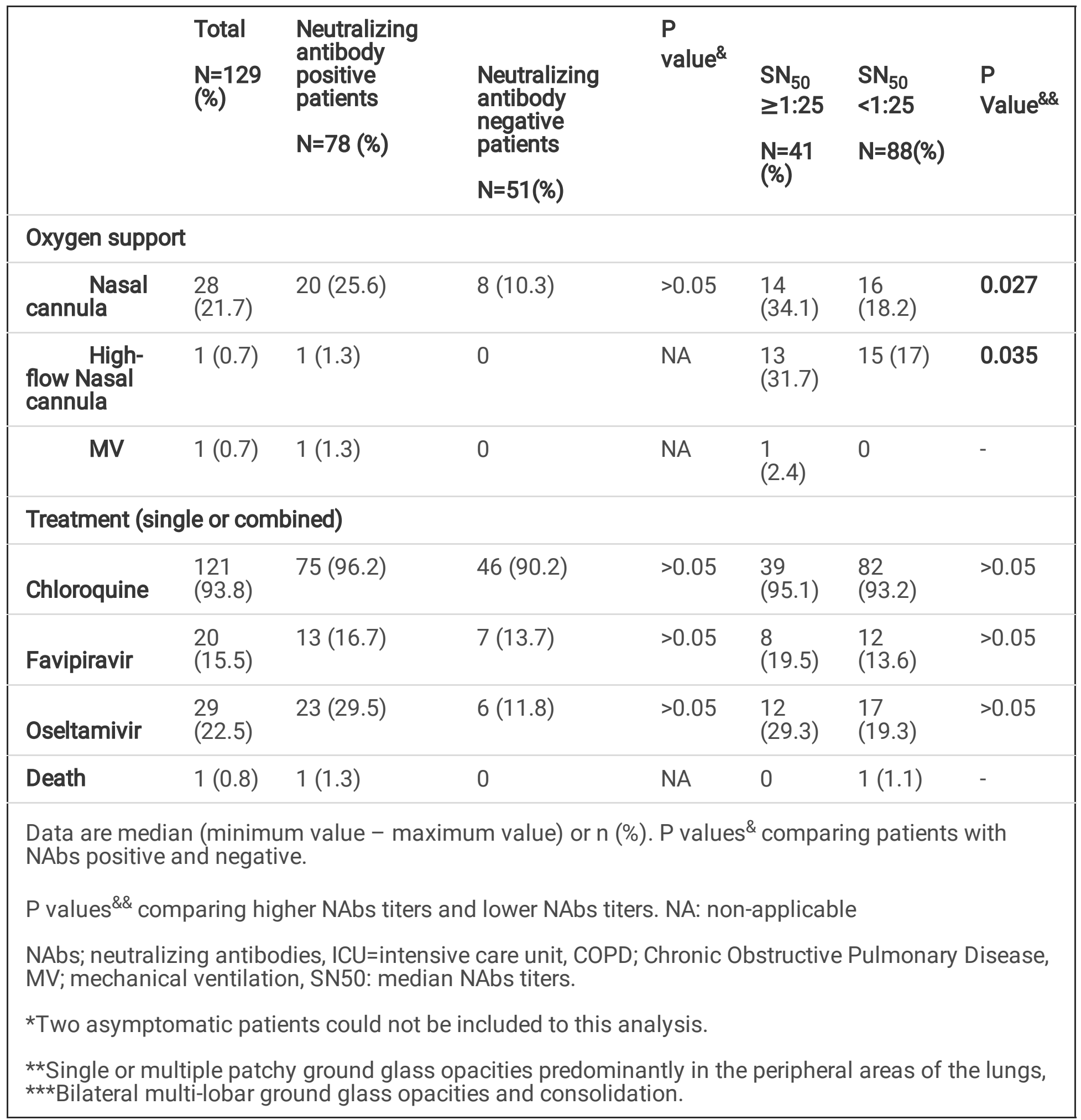

Table 2. Laboratory parameters of the patients with COVID-19 on admission 


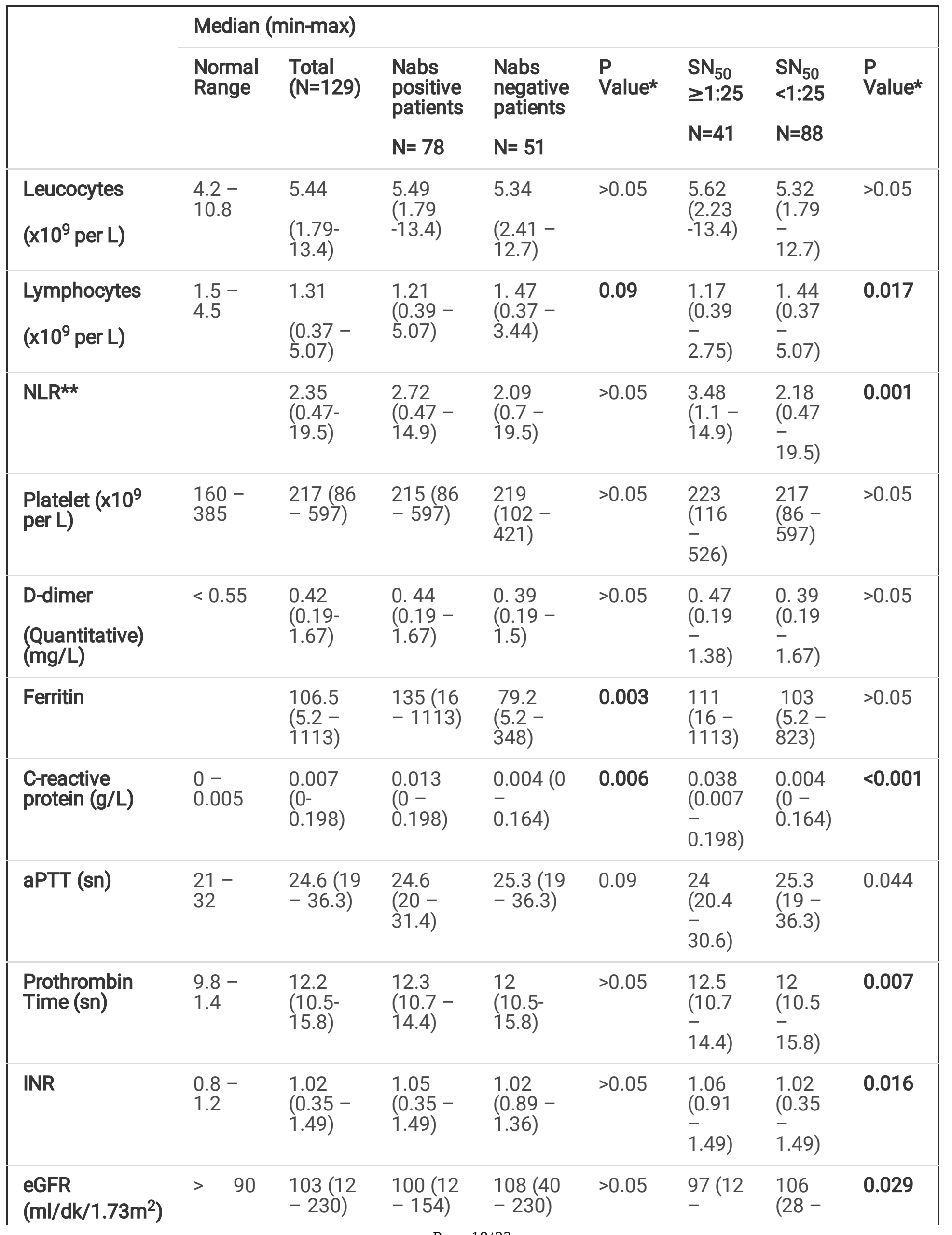




\begin{tabular}{|c|c|c|c|c|c|c|c|c|c|}
\hline & & & & & & & 148) & 230) & \\
\hline $\begin{array}{l}\text { Aspartate } \\
\text { amino } \\
\text { transferase } \\
(\mathrm{U} / \mathrm{L})\end{array}$ & $<$ & 35 & $\begin{array}{l}24(10 \\
-261)\end{array}$ & $\begin{array}{l}26(10 \\
-261)\end{array}$ & $\begin{array}{l}19(11- \\
94)\end{array}$ & 0.003 & $\begin{array}{l}29(11 \\
-261)\end{array}$ & $\begin{array}{l}22(10 \\
-94)\end{array}$ & 0.008 \\
\hline $\begin{array}{l}\text { Alanine amino } \\
\text { transferase } \\
\text { (U/L) }\end{array}$ & $<$ & 50 & $\begin{array}{l}25(3- \\
266)\end{array}$ & $\begin{array}{l}30(3- \\
266)\end{array}$ & $\begin{array}{l}22(9- \\
199)\end{array}$ & 0.09 & $\begin{array}{l}30(13 \\
- \\
266)\end{array}$ & $\begin{array}{l}23(3- \\
199)\end{array}$ & 0.062 \\
\hline $\begin{array}{l}\text { Lactate } \\
\text { dehydrogenase } \\
\text { (U/L) }\end{array}$ & $\begin{array}{l}120 \\
246\end{array}$ & & $\begin{array}{l}230 \\
(123- \\
735)\end{array}$ & $\begin{array}{l}245 \\
(136- \\
735)\end{array}$ & $\begin{array}{l}197 \\
(123- \\
375)\end{array}$ & $\dot{0} 001$ & $\begin{array}{l}249 \\
(146 \\
-735)\end{array}$ & $\begin{array}{l}205 \\
(123 \\
- \\
535)\end{array}$ & $\begin{array}{l}<.001 \\
0.00\end{array}$ \\
\hline $\begin{array}{l}\text { Creatine kinase } \\
\text { (U/L) }\end{array}$ & $\begin{array}{l}32- \\
294\end{array}$ & & $\begin{array}{l}91(26 \\
-2183)\end{array}$ & $\begin{array}{l}112(26 \\
-2183)\end{array}$ & $\begin{array}{l}74(33- \\
304)\end{array}$ & 0.001 & $\begin{array}{l}139 \\
(33- \\
2183)\end{array}$ & $\begin{array}{l}81(26 \\
-1102)\end{array}$ & $\begin{array}{l}<.001 \\
0\end{array}$ \\
\hline $\begin{array}{l}\text { Nabs; neutralizin } \\
\star P \text { values indicat } \\
P<.05 \text { was cons }\end{array}$ & $\begin{array}{l}\text { antibc } \\
\text { differ } \\
\text { dered } s\end{array}$ & $\begin{array}{l}\text { odie } \\
\text { rence } \\
\text { stati }\end{array}$ & $\begin{array}{l}\text { NLR; Neu } \\
\text { s between } \\
\text { tically sign }\end{array}$ & $\begin{array}{l}\text { rophil Lym| } \\
\text { JAbs positi } \\
\text { ficant. }\end{array}$ & $\begin{array}{l}\text { hocyte Rat } \\
\text { e and nega }\end{array}$ & ive patier & & & \\
\hline
\end{tabular}

\section{Figures}




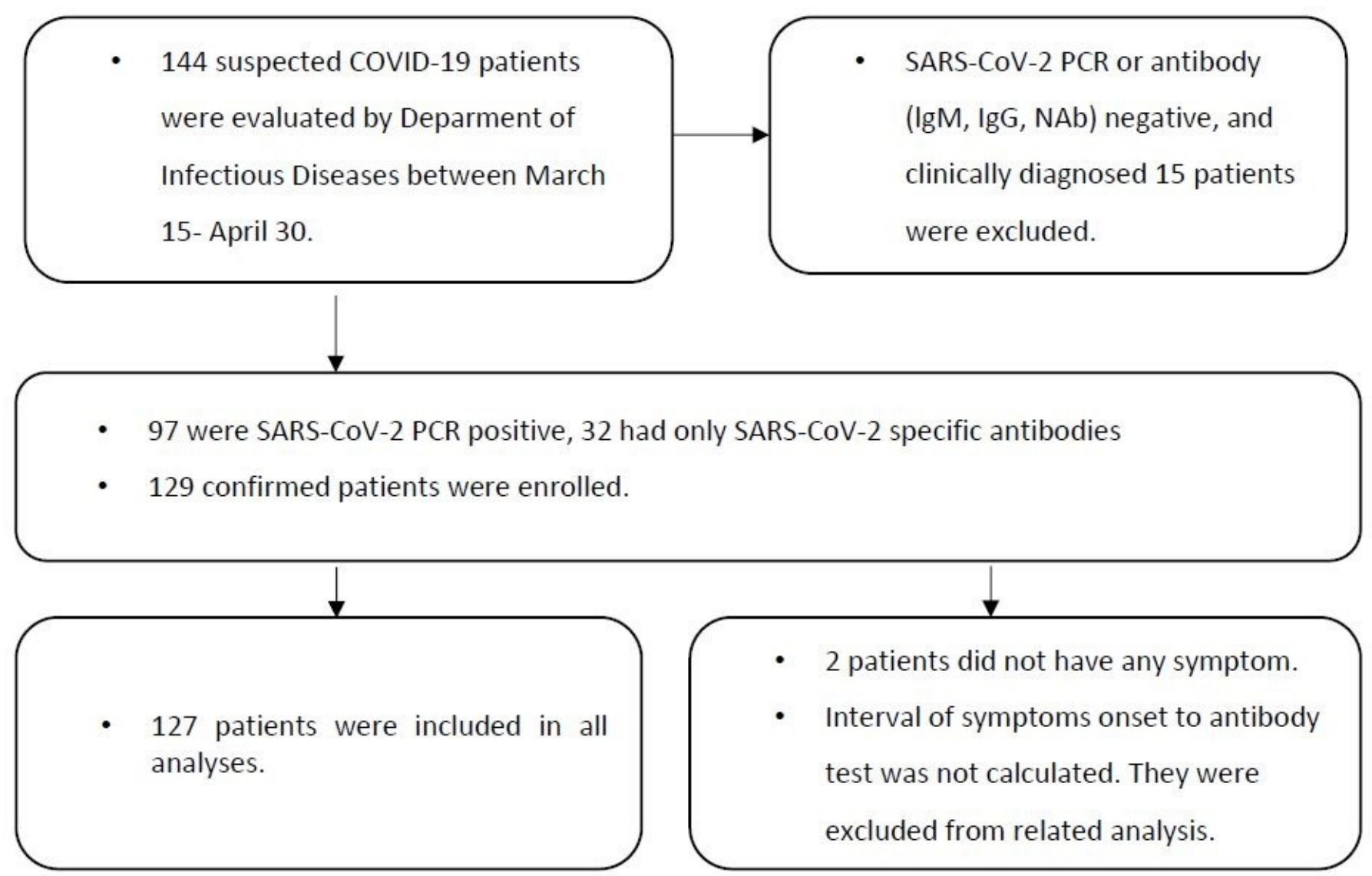

Figure 1

Flowchart of the study 


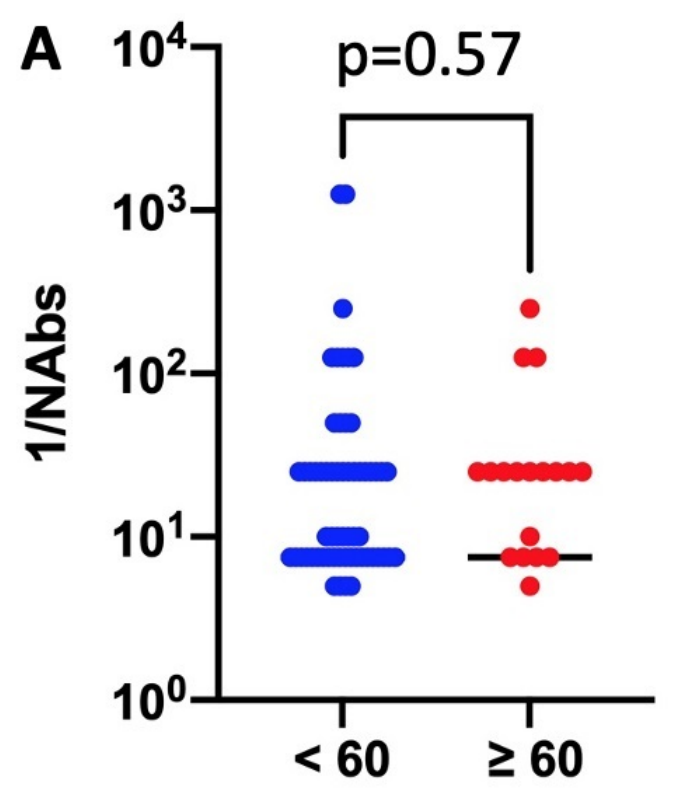

Age

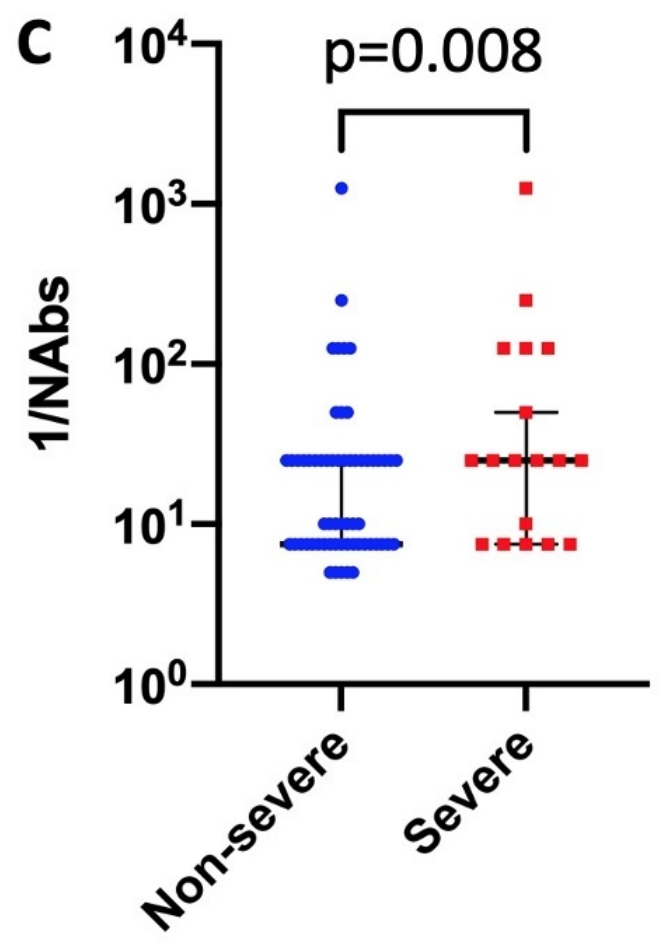

Patients' severity

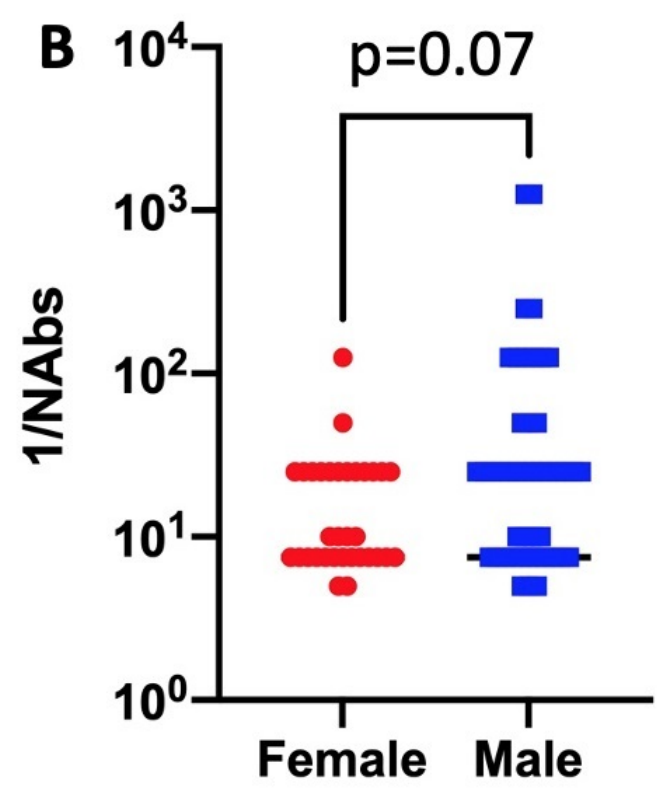

Gender

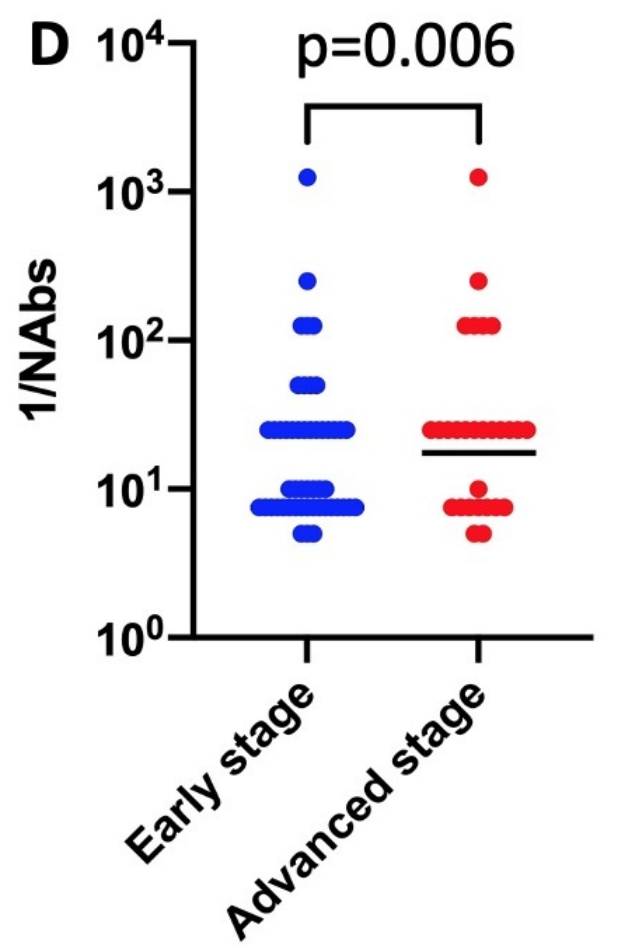

Thorax CT abnormality

Figure 2

Distribution of neutralizing antibody titers against Severe Acute Respiratory Syndrome-Coronavirus- 2 in different patient groups CT: Computed tomography, NAb: Neutralizing antibody 


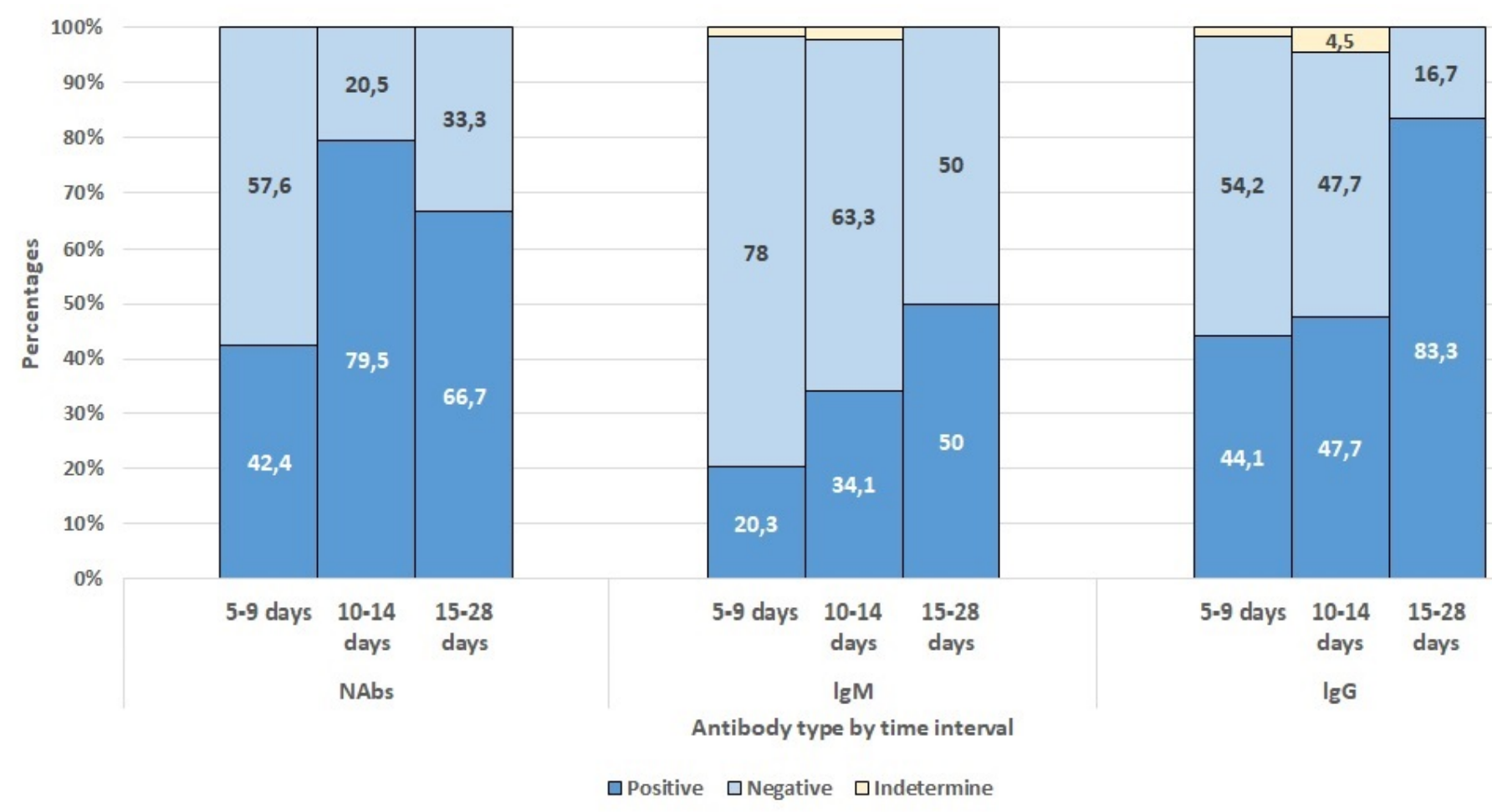

\section{Figure 3}

Seroconversion Characteristics of Severe Acute Respiratory Syndrome-Coronavirus-2 Specific Neutralizing antibody(NAb), Immunoglobulin M(IgM), and Immunoglobulin G (IgG)
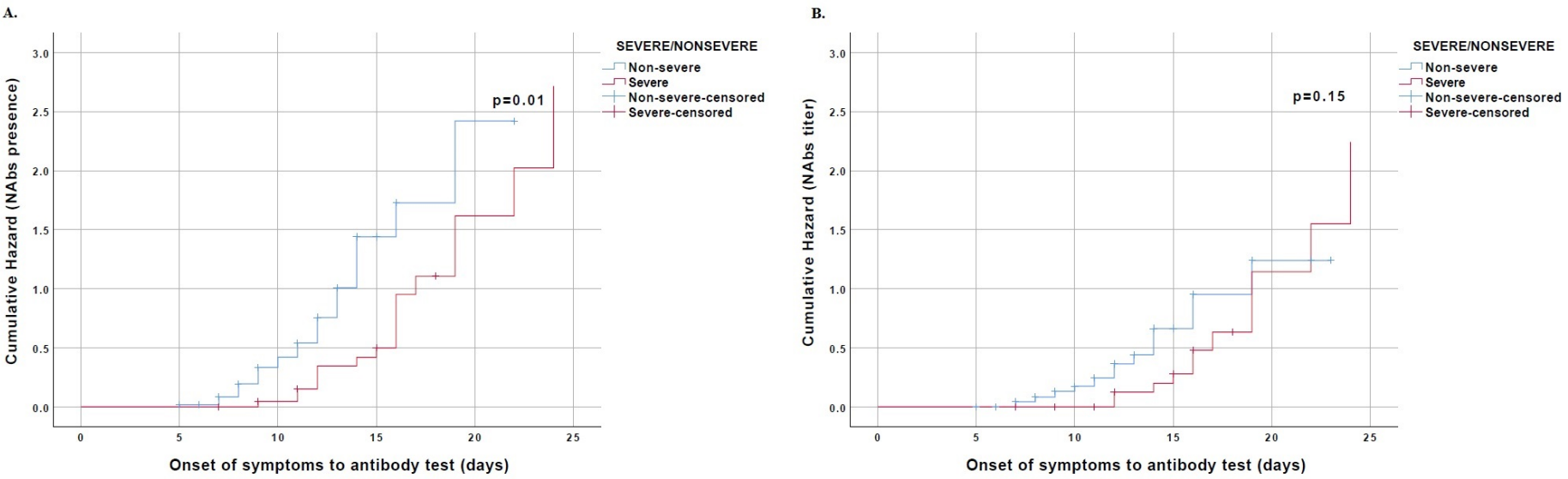

\section{Figure 4}

Hazard curves of higher neutralizing antibody (NAbs) titer or NAbs presence for severity of patients A. The hazard ratio of the NAbs presence to severe and non-severe disease was 0.49 (95\% Confidence Interval: $0.28-0.87)$. B. The hazard ratio of the higher NAbs titer to severe and non-severe disease was $0.58(95 \%$ Confidence Interval: 0.27-1.21).

\section{Supplementary Files}


This is a list of supplementary files associated with this preprint. Click to download.

- Supplementaryfile.ProductionofRecombinantRBD.docx 